\title{
Audits of emergency trolleys' contents in selected hospitals in Botswana
}

\author{
Authors: \\ Lakshmi Rajeswaran ${ }^{1,2}$ \\ Valerie J. Ehlers ${ }^{1}$ \\ Affiliations: \\ ${ }^{1}$ Department of Health \\ Studies, University of South \\ Africa, South Africa \\ ${ }^{2}$ Department of Nursing, \\ University of Botswana, \\ Botswana \\ Correspondence to: \\ Valerie Ehlers \\ Email: \\ ehlervj@unisa.ac.za \\ Postal address: \\ PO Box 65075, Erasmusrand, \\ Pretoria 0165, South Africa \\ Dates: \\ Received: 17 Sept. 2011 \\ Accepted: 25 Apr. 2012 \\ Published: 17 July 2012 \\ How to cite this article: \\ Rajeswaran, L. \& Ehlers, V.J., \\ 2012, 'Audits of emergency \\ trolleys' contents in selected \\ hospitals in Botswana', \\ Health SA Gesondheid 17(1) \\ Art. \#621, 7 pages. http:// \\ dx.doi.org/10.4102/hsag. \\ v17i1.621
}

(C) 2012. The Authors. Licensee: AOSIS OpenJournals. This work is licensed under the Creative Commons Attribution License.
Cardiac arrest is a life-threatening emergency situation. The outcome depends on timely and effective cardio-pulmonary resuscitation (CPR). Successful CPR attempts in hospitals require well-equipped emergency trolleys and properly functioning equipment, as well as staff members skilled in performing CPR. The study aimed to determine whether the emergency trolleys in Botswana's hospitals' wards or units met the expected standards. The contents of the emergency trolleys in 20 wards or units of two referral government hospitals in Botswana were audited by using a standardised checklist. No hospital ward or unit had all the expected equipment or drugs on its emergency trolley, some units failed to check their emergency trolleys' contents daily. All 20 hospital wards or units that participated in this study, needed to improve the contents and maintenance of their emergency trolleys, otherwise in-hospital CPR efforts in Botswana might be doomed to failure, losing lives that could have been saved if emergency trolleys' equipment and supplies had been up to standard.

Hartarres is ' $n$ lewensbedreigende noodsituasie. Die uitkoms word bepaal deur tydige en effektiewe kardio-pulmonale resussitasie (KPR). Suksesvolle KPR pogings in hospitale vereis goed toegeruste noodtrollies en toerusting wat behoorlik funksioneer, asook personeellede wat bedrewe is in die uitvoering van KPR. Die studie het gepoog om te bepaal of die noodtrollies in Botswana se hospitaalsale of eenhede aan die verwagte standaarde voldoen. Die inhoud van die noodtrollies in 20 sale of enhede van twee van Botswana se hospitale is ge-ouditeer deur 'n gestandardiseerde kontrolelys te benut. Geen hospitaalsaal of eenheid het al die verwagte toerusting of drogerye op sy noodtrollie gehad nie, sommige eenhede het nie hulle noodtrollies se inhoud gereeld gekontroleer nie. Al 20 hospitaalsale of eenhede wat aan die studie deelgeneem het, moet die inhoud en instandhouding van hulle noodtrollies verbeter, anders kan in-hospitaal KPR pogings in Botswana tot mislukkings gedoem wees, waardeur lewens verloor word wat gered kon gewees het, indien die noodtrollies se inhoud op standaard was.

\section{Introduction}

Cardiac arrest is defined as the sudden cessation of breathing and the inadequate circulation of blood by the heart. It may occur at any time or in any setting (Jacobs \& Nadkarni 2004:3387). Cardiopulmonary arrest is a common and treatable cause of premature death. The earlier effective treatment is provided, the more likely is the patient's survival (Colquhoun, Gabbot \& Mitchell 2001:2).

Cardiopulmonary resuscitation (CPR) is a critical component of Basic Life Support (BLS) and is the established first-line response to cardiac arrest in the interim before defibrillation and Advanced Life Support (ALS) become available (Madden 2006:218). According to Handley et al. (2005:S7), CPR refers to the attempts to establish and maintain airway patency by supporting breathing and circulation without the use of equipment other than the protective shield or face mask.

\section{In-hospital cardiopulmonary resuscitations and the importance of well- equipped emergency trolleys}

The resuscitation trolley is mainly used for the purpose of CPR and management of other emergencies in any health care setting (Remote Health Atlas 2007:1).

In some parts of the world, the emergency trolley is also called a 'crash cart'. The essential equipment for resuscitation includes more than 100 items such as drugs, syringes, electrodes, defibrillators and easy access to electrical power (Donchin 2002:393). A standard checklist with a list of compulsory equipment and drugs must be on the trolley to assist in systematic, visual and functional testing (Dyson \& Smith 2002:137). 
In-hospital cardiopulmonary arrest requires an immediate response to increase the likelihood of a successful outcome. Most cardiac arrests are sudden and unexpected occurrences, requiring immediate actions. Successful CPR relies on the availability and correct functioning of essential resuscitation equipment and recommended drugs available from a wellequipped resuscitation trolley, as well as on skilled personnel (Dyson \& Smith 2002:137).

The Resuscitation Council of the United Kingdom (2004) requires that the recommended minimum equipment must be available for the successful management of adult cardiopulmonary arrests. The National Patient Safety Agency (2008:8) in the United Kingdom (UK) reported a number of incidents that involved missing or broken equipment during CPR. A separate survey of emergency trolleys conducted in selected UK hospitals found that the availability of necessary equipment varied from hospital to hospital (Hogh et al. 2005:409). Botswana has no policies or guidelines about emergency trolleys. The UK guidelines were adopted as a baseline because they seemed to be similar to those used by other countries. It was deemed unnecessary to do a comparative study of the guidelines of different countries, in order to identify shortcomings in the emergency trolleys' contents and maintenance in Botswana.

The CPR standards for clinical practice and training in the UK recommend that the responsibility for checking the resuscitation equipment rests with each ward and that the emergency trolley should be checked on a daily basis (Gabbot et al. 2005:179). Furthermore, the CPR standards for training in clinical practice (UK) suggest that the equipment should be standardised throughout the hospital to aid familiarity. The emergency trolley should be located in the same area in each ward.

The frequency of checking the equipment depends on the anticipated frequency of its utilisation. In critical care emergency units, the equipment should be checked at the beginning of each shift while in the general wards they should be checked on a daily basis (Dyson \& Smith 2002:137).

Studies conducted in countries like the UK, United States of America (USA) and Thailand indicate that CPR attempts were delayed due to the non-availability of drugs and functional equipment (Smith et al. 2008:14; Strzyzewski 2006:10; Suraseranivongse et al. 2005:188). Any shortage or absence of equipment and supplies, non-functioning equipment and the storage of the emergency trolleys in unknown locations, could adversely affect the timely initiation of CPR efforts (Desalu, Kushimo \& Akinlaja 2006:517; Ranse \& Arbon 2008:38).

Finn and Jacobs (2003:470) reported serious deficiencies in the emergency trolleys of Australian hospitals concerning storage, maintenance and resuscitation equipment. Donchin (2002:393) asserts that unless nurses and doctors are familiar with the drugs and equipment of emergency trolleys, crucial time will be wasted in instituting effective CPR actions.

\section{Problem statement}

In Botswana, nurses constitute the core of the health-related workforce, and they manage primary, secondary and tertiary health care facilities throughout the country. All nurses are expected to function efficiently during emergency resuscitations. Nurses can only function efficiently if resources, such as defibrillators and drugs necessary for treating cardiac emergencies, are available, implying that the emergency trolleys should contain all the required drugs, and the equipment should be in a working condition. No reports could be traced about audits conducted on the state of emergency trolleys in Botswana's hospitals, implying that it was unknown what the state of emergency trolleys was in Botswana's hospitals.

There are no emergency trolley guidelines in Botswana and thus also no hospital policies in this regard. Consequently the guidelines developed by the Resuscitation Council of the United Kingdom (2004) were used to identify shortcomings of the emergency trolleys in Botswana's hospitals.

\section{Objectives of the study}

The objectives of the study were to audit the state of the emergency trolleys in Botswana's hospital wards, and based on these results, to make recommendations for improving the maintenance of these trolleys, and to recommend policies and guidelines for emergency trolleys in Botswana's hospitals.

\section{Significance of and rationale for the study}

The success or failure of implementing CPR in a hospital depends on the competency of the nurse or doctor and on the adequacy of the contents of the emergency trolley. It is a dire life-saving necessity that the equipment of the emergency trolleys should be up to standard for implementing successful CPR. If audits of the contents of preceding emergency trolleys should indicate shortcomings, then addressing these shortcomings could save patients' lives.

\section{Research method and design Design}

A quantitative, non-interventional, descriptive research design was used to audit the contents of emergency trolleys at two major hospitals in Botswana. The following items were audited: the contents of the emergency trolley, the functionality of the defibrillator, electrocardiograph (ECG) monitor, the availability of specific drugs, and the availability or status of the ambu bag.

\section{Population}

The population for this study comprised all government hospitals in Botswana. However, the target and accessible population of hospitals comprised the two largest government referral hospitals located in Gaborone and in Francistown, the two largest cities in Botswana. These two referral hospitals were chosen for the study because they are supplied with modern facilities such as emergency trolleys, 
ECG monitors and defibrillators. Few smaller government hospitals would have these facilities in Botswana.

\section{Sample and sampling technique}

The emergency trolleys from ten units or wards were selected, namely: the male and female medical, surgical and orthopaedic wards, as well as those from the gynaecology, maternity, intensive care units (ICUs) and accident and emergency (A\&E) units were audited at both participating hospitals in Botswana. The need to initiate CPR as an emergency intervention could arise at any time in any of these wards.

\section{Data collection methods}

The audits were conducted at the two hospitals from January till June 2008. The data were collected from the emergency trolleys of ten wards or units of both hospitals, as specified under sampling.

For the purpose of conducting the audit, the checklist of the equipment recommended by the Resuscitation Council of the United Kingdom (2004:1) was adopted to evaluate the practices in Botswana, as no Botswana policies and guidelines about hospitals' emergencies trolleys existed. The checklist made provision for checking the various categories of items that had to be included on the emergency trolley such as the equipment needed to maintain the airway, breathing and circulation, drugs, electrical equipment such as defibrillators and cardiac monitors; and additional equipment like disposable razors, scissors and boxes for disposing used sharp instruments such as injection needles, compared to the expected contents of emergency trolleys. One researcher collected all the data by comparing the actual contents of the emergency trolleys of the 20 participating hospital wards or units to the items on the checklist.

\section{Description of an emergency trolley in Botswana}

The Resuscitation Council of the United Kingdom (2004:1) divides the required contents of the emergency resuscitation trolley into four sections: airway equipment, circulation equipment, drugs and additional items.

Emergency resuscitation trolleys in Botswana's hospitals had three compartments. The upper compartment contained the equipment necessary for maintaining the patency of the patient's oropharyngeal airway and breathing capacity by any kind of Guedal-pattern airway device. The next compartment contained a defibrillator. The bottom compartment contained those items necessary for managing circulation. The drugs necessary to revive the patient were stored on the one side of the first compartment. Jevon (2004:28) asserts that all resuscitation equipment and the layout of the resuscitation trolleys should be strictly standardised throughout an institution. A total of 88 items should have been kept on each emergency trolley in the wards or units of the two hospitals that participated in the study.
Resuscitation Council of the United Kingdom: Required availabilty of equipment on emergency trolley

Airway:

- Pocket mask with oxygen port (should be widely available in all clinical areas)

- Self inflating resuscitation bag with oxygen reservoir and tubing (ideally, the resuscitation bag should be single use - if not, it should be equipped with a suitable filter)

- Clear face masks, sizes 3, 4 and 5

- Oropharyngeal airways, sizes 2, 3 and 4

- Nasopharyngeal airways, sizes 6 and 7

- Portable suction equipment

- Yankauer suckers

- Tracheal suction catheters, sizes 12 and 14

- Laryngeal mask airways (sizes 4 and 5), or ProSeal LMAs (sizes 4 and 5), or Combitube (small)

- Magill forceps

- Tracheal tubes - oral, cuffed, sizes 6,7 and 8

- Gum elastic bougie or equivalent device

- Lubricating jelly

- Laryngoscope handles (x 2) and blades (standard and long blades)

- Spare batteries for laryngoscope and spare bulbs (if applicable)

- Fixation for tracheal tube (such as ribbon gauze or tape)

- Scissors

- Selection of syringes

- Oxygen mask with reservoir (non-rebreathing) bag

- Oxygen cylinders

- Oxygen cylinder key.

Circulation:

- Defibrillator (shock advisory module and or external pacing facility - depending on local policy)

- ECG electrodes

- Defibrillation gel pads or self-adhesive defibrillator pads (preferred)

- Selection of intravenous cannulae

- Selection of syringes and needles

- Cannula fixing dressings and tapes

- Seldinger central venous catheter kit

- Intravenous infusion sets

- $0.9 \%$ sodium chloride - $1000 \mathrm{~mL}$ x 2

- Arterial blood gas syringes

- Tourniquet.

Drugs: Immediately available pre-filled syringes:

- Adrenaline (epinephrine) $1 \mathrm{mg}(1: 10,000)$ x 4

- Atropine $3 \mathrm{mg} \times 1$

- Amiodarone $300 \mathrm{mg} \times 1$.

Other readily available drugs: Intravenous medications:

- Adenosine 6 mg x 10

- Adrenaline $1 \mathrm{mg}(1: 10$ 000) x 4

- Adrenaline $1 \mathrm{mg}(1: 1000) \times 2$

- Amiodarone $300 \mathrm{mg} \times 1$

- Calcium chloride $10 \mathrm{~mL}$ of $100 \mathrm{mg}$ per $\mathrm{mL}$ x 1

- Chlorphenamine 10 mg x 2

- Furosemide $50 \mathrm{mg} \times 2$ 
- Glucose $10 \% 500 \mathrm{~mL}$ x 1

- Hydrocortisone $100 \mathrm{mg} \times 2$

- Lidocaine 100 mg x 1

- Magnesium sulphate 50\% solution $2 \mathrm{~g}(4 \mathrm{~mL})$ x 1

- Midazolam $10 \mathrm{mg}$ x 1

- Naloxone 400 mcg x 5

- Normal saline $10 \mathrm{ml}$ ampoules

- Potassium chloride for injection

- Sodium bicarbonate $8.4 \%$ - $50 \mathrm{~mL}$ x 1 .

Additional items: (1) Clock, gloves, goggles and aprons, (2) audit forms (3) sharps container, (4) clinical waste bag, (5) large scissors; alcohol wipes, (6) blood sample specimen bottles, (7) a sliding sheet or similar device (for safer handling) (Resuscitation Council of the United Kingdom [2004:1]).

\section{Data analysis}

The data were analysed by using the Statistical Package for Social Sciences (SPSS) (Version 15.0) as well as the Microsoft Excel computer program to generate figures and graphs. Frequency distributions summarised the data displayed in figures and tables, expressed in percentages for comparative purposes.

\section{Ethical considerations}

No persons (other than the researcher) were involved in the audits of the contents of the emergency trolleys in selected wards of the two largest public hospitals in Botswana. Permission to conduct the study was granted by Botswana's Ministry of Health and the managers of the hospitals concerned as well as the manager of every participating hospital ward or unit. The Research and Ethics Committee of the Department of Health Studies, University of South Africa, also granted approval that the study could be conducted (issued under the student number of the first author).

\section{Validity and Reliability}

The audit checklist was based on the contents of an emergency trolley as specified by the Resuscitation Council of the United Kingdom (2004:1) developed by a panel of resuscitation experts. Two health service managers of referral hospitals where CPR situations could arise, an experienced nurse researcher, a lecturer in pre-hospital emergency care, one anaesthetist from one of the referral hospitals, and the CPR instructor from a private organization (Medical Rescue International Botswana) agreed that the items on the checklist were required on any emergency trolley in Botswana, implying that face, construct and content validity had been accepted.

Prior to collecting the data, the researcher completed the checklist in two hospital wards that did not participate in the actual study in order to pretest the instrument. No problems were encountered and the checklist was accepted. Similar shortcomings were noted in the emergency trolleys of both wards.

One researcher collected all the data and completed all the audit checklists, ensuring that no inter-rater variability existed. As every item on the checklist had been judged by four experts to be relevant to the contents of an emergency trolley, and as these were based on the requirements of the UK Emergency Council, the reliability of the instrument could not be questioned. On the advice of a statistician, no Cronbach alpha was compiled as every item was indeed relevant to the contents of an emergency trolley, making Cronbach alpha coefficients superfluous.

\section{Discusion of results}

\section{Availability of equipment}

The research results revealed that an average of $45 \%$ of the emergency trolley equipment was present in hospital A but an average of only $26 \%$ in hospital B.

According to the standard checklist, a total of 88 pieces of equipment should have been present on the emergency trolleys of the ten wards or units studied in each hospital. The equipment on the emergency trolleys of the medical wards was low in comparison to the equipment available in the ICUs. The emergency trolley of the male medical ward in hospital A contained $42 \%$, whereas the male medical ward in hospital B contained only $8 \%$ of the required equipment. The emergency trolley of the female medical ward of hospital A had $34 \%$, and the female medical ward of hospital B had only $24 \%$, of the equipment stipulated on the checklist.

Hospital A's wards or units revealed a better overall distribution of emergency trolley equipment compared to the wards of hospital B. Finn and Jacobs (2003:470) indicated that Australian hospitals' emergency trolleys were not stored properly, and did not maintain their resuscitation equipment effectively. The findings of this study indicate that the two hospitals in Botswana experienced similar problems.

\section{Comparison of equipment of the emergency trolleys of the ten wards of the two referral hospitals}

The availability of equipment that was compared between the hospitals, included equipment required for maintaining airway patency and breathing, fluid and circulation maintenance, as well as emergency drugs, electrical and hardware equipment, the frequency of checking the contents of the emergency trolleys and the available policies in the units.

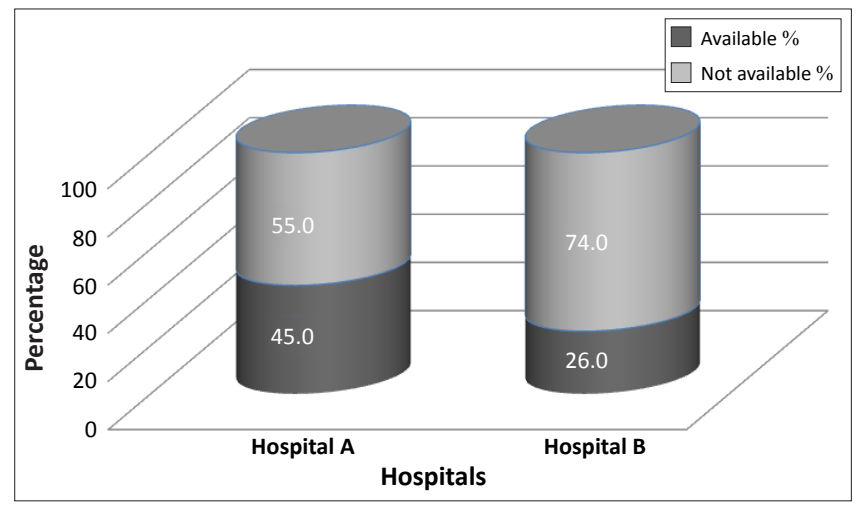

FIGURE 1: Distribution of equipment available on the emergency trolleys of hospitals A and B. 


\section{Airway and breathing}

According to the Resuscitation Council of the United Kingdom (2004:1) and the checklist, the emergency trolley should contain 44 specified items of equipment to maintain the patient's airway's patency and breathing. The present study determined that the A\&E units and the ICUs of the two hospitals contained more equipment than the other hospital wards or units, although they also did not have all of the 44 stipulated items.

The A\&E unit in hospital A had 29 items of the specified equipment (equivalent to $66 \%$ ) whereas the $A \& E$ unit in hospital B had only 14 (32\%) items. Both the ICU of hospital $B$ and the ICU of hospital A had 22 (50\%) items of equipment. The male medical ward in hospital B contained none of the required items $(0 \%)$ for an emergency trolley. This absence of equipment could hold serious consequences for implementing effective CPR in these units.

However, this situation is not unique to Botswana. The National Patient Safety Agency (2008:8) in the UK reported incidents that involved missing or broken equipment on emergency trolleys. A survey of emergency trolleys in the UK hospitals during 2002-2003, reported that the availability of equipment varied from one hospital to another (Hogh et al. 2005:409).

\section{Distribution of equipment for fluid and circulation maintenance equipment}

According to the Resuscitation Council of the United Kingdom (2004:1), ten items of equipment are required for the management of fluid and circulation. The audits of emergency trolleys in ten wards at two Botswana hospitals revealed that $59 \%$ of these items were available overall in hospital A, while $52 \%$ were present in the 10 wards of hospital B. More than seven wards in each hospital had $50 \%$ or more of the required pieces of equipment needed for maintaining fluid balance and circulation.

The ICU in hospital B had only $30 \%$ but the ICU in hospital A had $60 \%$ of these pieces of equipment. The A\&E units fared better with $80 \%$ and $70 \%$ in hospitals $\mathrm{A}$ and $\mathrm{B}$ respectively. While the female surgical ward in hospital A had only $40 \%$

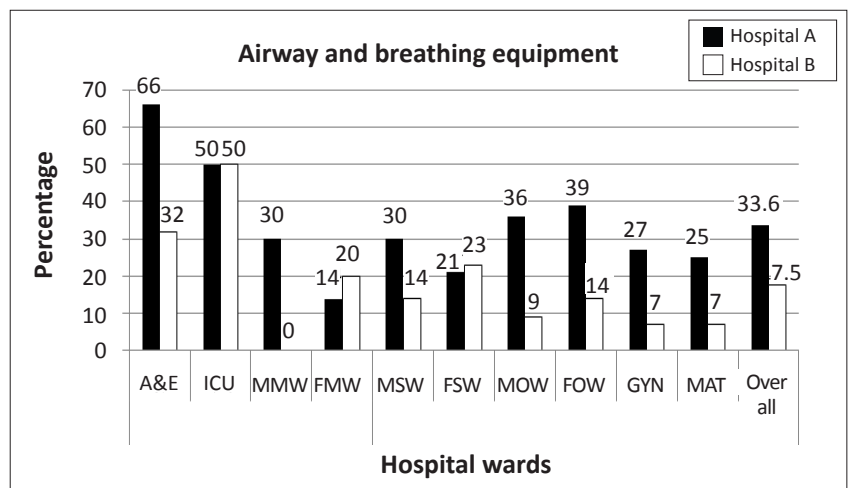

$A \& E$, accident and emergency unit; ICU, intensive care unit; MMW, male medical ward; FMW, female medical ward ; MSW, male surgical ward; FSW, female surgical ward; MOW, male orthopaedic ward; FOW, female orthopaedic ward; GYN, gynaecology ward; MAT, maternity ward.

FIGURE 2: Airway and breathing maintenance equipment in the two hospitals. of the equipment, hospital B had three wards with that low percentage of available equipment. All wards or units should have the necessary supplies and equipment for maintaining fluid balance and circulation during emergencies, but this is critically important in ICU and A\&E units.

\section{Availability of emergency drugs}

The first-line and second-line drugs are vital elements for providing effective ALS. The non-availability of sufficient amounts of the necessary resuscitation drugs simply means that the resuscitation team will be unable to administer effective ALS (Desalu et al. 2005:517). The present study found that some of the essential drugs, that should be present on all emergency trolleys in the wards of the two referral hospitals, were missing. A comparison of the two hospitals shows that hospital A had more of the essential drugs available (42.5\%) than hospital B (33.3\%). According to the recommendations of the Resuscitation Council of the United Kingdom (2004:4), all emergency trolleys should contain twelve first-line and second-line drugs. The audit information indicates that drugs were more available in the ICUs $(50 \%)$ than in other wards (35\%). If drugs are unavailable during emergencies, patients could lose their lives. Maintaining the availability of emergency drugs on emergency trolleys is thus a matter of life-and-death.

\section{Availability of electrical and hardware equipment}

A total of 23 electrical and hardware items need to be available on all correctly stocked emergency trolleys. These essential pieces of equipment include a manual defibrillator and ECG electrodes.

The female orthopaedic ward and the maternity ward of hospital B had none of the necessary electrical equipment for resuscitation (0\%). Two wards or units $(20 \%)$ in hospital A and four wards or units (40\%) in hospital B had no manual defibrillators. A similar absence of defibrillators was reported in studies conducted by Suraseranivongse et al. in Thailand (2006:188) and Gnanalingham, Harris and Didcock in the UK (2006:1677). The impossibility of early defibrillation because of the absence of functional defibrillators, would impact negatively on patients' CPR outcomes.

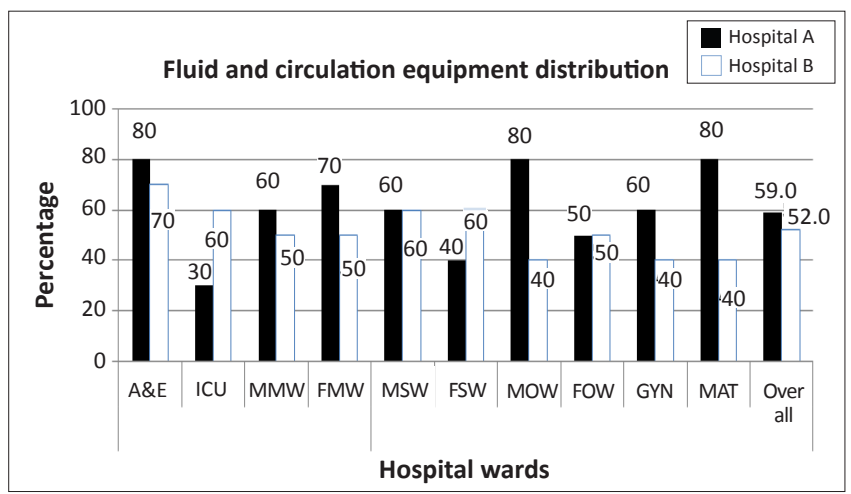

$A \& E$, accident and emergency unit; ICU, intensive care unit; MMW, male medical ward; FMW, female medical ward ; MSW, male surgical ward; FSW, female surgical ward; MOW, male orthopaedic ward;
gynaecology ward; MAT, maternity ward.

FIGURE 3: Distribution of fluid and circulation equipment by wards or units in the two hospitals. 
TABLE 1: Frequency of the checking of emergency trolleys.

\begin{tabular}{lcccccccccc}
\hline Hospitals & A\&E & ICU & MMW & FMW & MSW & FSW & MOW & FOW & GYN & MAT \\
Hospital A & D & W & I & I & I & I & F & I & I & I \\
Hospital B & I & D & I & I & I & I & I & I & । & I \\
\hline
\end{tabular}

D, Daily; W, Weekly; F, Fortnightly; I, Infrequently.

\section{Frequency of the checking of the contents of emergency trolleys}

The emergency trolley checklist book from each ward indicated that the emergency trolleys had been checked on a daily basis only in the A\&E unit of hospital A and in the ICU of hospital B. In the remaining wards, the practice of checking the trolley was apparently infrequent and/or not recorded in the checklist book. Ideally all wards or units should check their emergency trolleys once every day, but the A\&E units as well as the ICUs, should check their emergency trolleys at the beginning of every shift.

Jevon (2004:29) recommends that each clinical department should be responsible for checking its own resuscitation equipment - preferably on a daily basis. The functionality and efficiency of the electrical equipment and other hardware on emergency trolleys should also be checked frequently and serviced on a regular basis. Smith et al. (2008:4) found that because basic trolley-checking procedures had not been followed in the UK, these trolleys often lacked essential items, and were therefore of little use for responding to CPR emergencies. They also found that some emergency trolleys were only checked every third day, and some remained unchecked for up to nine days (Smith et al. 2008:4).

\section{Guidelines followed in the wards}

Audits of the procedure manuals of the two hospitals revealed that no standard guidelines were followed in any ward for maintaining the emergency trolley. Desalu et al. (2006:517) showed that failure to follow standardised guidelines, negatively affected the quality of teaching CPR and the practice of CPR in developing countries. According to Shuster (2006:38), resuscitation guidelines describe the best current global practices from available research evidence, and they also describe the consensus of experts where sufficient evidence is unavailable. The guidelines and policies help to improve survival rates, the quality of life of those who survive, and the quality of post-resuscitation care (Spearpoint 2008:48).

To enhance adherence to checking procedures, Nolan (2000:320) identified five broad categories of tactics: reducing the complexity of the system, optimising information, wise automation, use of constraints and mitigating the unwanted side-effects of change. Dyson and Smith (2002:137) concur with Nolan's principles, which could be applied to resuscitation equipment. So-called 'intelligient trolleys' that could automatically produce reminders or visual signals when equipment is missing, could help nurses to remember to check a piece of equipment prior to CPR. Such automation could increase safety and the nurses' confidence levels during resuscitation, but was unavailable in Botswana during this study's data collection phase. However, the same objective could be reached by sustained effective daily checking and replenishing of all items on each emergency trolley.

\section{Limitations of the study}

The study findings are limited to the two referral government hospitals in Botswana. The findings cannot be generalised to other government hospitals and clinics in Botswana, nor to private hospitals or organizations.

\section{Recommendations}

Improvements in CPR outcomes might be achieved by the standardisation of resuscitation equipment and uniform maintenance standards using standardised checklists for ensuring that the emergency trolleys remain well stocked and fully functional. Regular audits and in-service education could improve the system of checking, replacing and repairing the equipment of the emergency trolleys. Portable oxygen, ambu bags and suction devices should be available in case of electricity failures.

Regular audits should be done by nurse admininstrators of specific emergency trolleys and the outcomes of these audits should be recorded for future comparative purposes. Resuscitation equipment should be checked regularly, implying daily in most wards, but at the beginning of every shift in the intensive care as well as in the accident and emergency units. Unit and hospital managers should be held accountable for the maintenance, checking and recording of all items that should be on emergency trolleys.

The equipment that is used for CPR (including defibrillators) and the layout of the equipment and the drugs on resuscitation trolleys should be standardised throughout each institution. The emergency trolley's location should be in identical locations in all wards or units.

Any harm that is experienced by patients - including mortality - because of missing, faulty or expired equipment or the unavailability of necessary CPR medications during an arrest should be described in writing. Such incidents should be reported to the resuscitation committee of the hospital concerned, and to the Ministry of Health of Botswana so that remedial actions can be instituted.

Minimising the complexity of the emergency trolley, standardising the equipment, standardising the checklist, enhancing nurses' knowledge levels, identifying deficits and immediate replacement of emergency equipment would reduce time delays and errors during CPR.

\section{Conclusion}

In the two participating hospitals in Botswana, the availbility of the equipment was inadequate, recommended basic trolley checking procedures were not followed, indicating possible unpreparedness for CPR emergencies. Failure to check the emergency trolleys' equipment regularly, the non- 
availability of emergency drugs and fluids, as well as nonfunctioning defibrillators, indicate that fatal delays might be encountered in instituting CPR in these hospital wards or units which would impact negatively on CPR outcomes in Botswana's hospitals.

\section{Acknowledgements}

We are grateful to the authorities that granted permission for this study to be conducted in Botswana, and to all hospital wards or units that participated in this study.

\section{Competing interests}

The authors declare that they have no financial or personal relationship(s) which may have inappropriately influenced them in writing this paper. No financial assistance was obtained for conducting this study.

\section{Authors' contributions}

LR conducted the study as part of her research for her DLitt et Phil project. V.J.E. (University of South Africa) was the joint supervisor for this study. LR obtained permission for the study and collected the data. V.J.E. guided the research process from its inception till its completion, in consultation with the supervisor. L.R. (University of South Africa \& University of Botswana) and V.J.E. combined efforts to write this article, based on part of the DLitt et Phil thesis, and to implement necessary revisions until its publication.

\section{References}

Colquhoun, M., Gabbot, D \& Mitchell, S., 2001, 'Cardiopulmonary resuscitation guidance for clinical practice and training in primary care', Resuscitation Council (UK) viewed 21 February 2012, from http://www.resus.org.uk

Desalu, L., Kushimo, O. \& Akinlaja, O., 2006, 'Adherence to CPR guidelines during peri- operative cardiac arrest in a developing country', Resuscitation 69(3), 517520. http://dx.doi.org/10.1016/j.resuscitation.2005.10.012, PMid:16563595

Donchin,Y., 2002, 'Resuscitation trolleys: human factors engineering', Quality and Safety in Health Care 11(4), 393. http://dx.doi.org/10.1136/qhc.11.4.393, PMid:12468708, PMCid:1758015
Dyson, E. \& Smith, G.B., 2002, 'Common faults in resuscitation equipment-guidelines for checking equipment and drugs used in adult CPR'. Resuscitation 55(2), 137149. http://dx.doi.org/10.1016/S0300-9572(02)00169-7

Finn, J.C. \& Jacobs, I.G., 2003, 'Cardiac arrest resuscitation policies and practices. A survey of Australian hospitals', Medical Journal of Australia 179(9), 470-474. PMid:14583077

Gabbot, D., Smith, G., Mitchell, S., Colquhoun, M., Nolan, J., Soar, J., Pitcher, D., Perkins, G., Phillips, B., King, B. \& Spearpoint, K., 2005, 'Cardiopulmonary resucitation standards for clinical practice and training in the United Kingdom Accident and Emergency Nursing 13(3), 171-179. http://dx.doi.org/10.1016/j. aaen.2005.04.004, PMid:16005631

Gnanalingham, M.G., Harris, G. \& Didcock, E., 2006, 'The availability and accessibility of basic paediatric resuscitation equipment in primary healthcare centres: cause for concern?' Acta Paediatrica 95(12), 1677-1679.

Handley, I.J., Koster, R., Monseieur, K., Perkins, G.D., Davies, S. \& Bossaert, L., 2005 'European resuscitation Council guidelines for resusictation. Adult basic life support and use of automated external defibrillators', Resuscitation 67S1, S7-S23.

Hogh, L., Kane, L., Bhalla, A. \& Ward, M.C., 2005, 'Variations in the provision of resuscitation equipment: survey of acute hospitals'. Postgraduate Medical Journal 81(1956), 409-410. http://dx.doi.org/10.1136/pgmj.2004.026930, PMid:15937210, PMCid:1743295

Jacobs, I.G. \& Nadkarni, V., 2004, 'Cardiac arrest and cardiopulmonary resuscitation outcome reports'. Circulation 110, 3385-3397, viewed 10 February 2007, from http://cir.ahajournals.org

Jevon, P., 2004, 'Standards for clinical practice and staff training in CPR', Nursing Times 100(47), 28-29.

National Patient Safety Agency of the UK (NPSA), 2008, 'Treatment for safety: why we need it. How do we do it', viewed 15 May 2009, from http://www.npsa.nhs.uk/ patietnsafety/humanfactors/teamworking

Madden, C., 2006, 'Undergraduate nursing students' acquisition and retention of CPR knowledge and skills', Nurse Education Today 26(3), 218-227. http://dx.doi. org/10.1016/j.nedt.2005.10.003, PMid:16314002

Nolan, T.W., 2000, 'System changes to improve patient safety', British Medical Journal 320(7237), 771-773. http://dx.doi.org/10.1136/bmj.320.7237.771, PMid:10720364 PMCid:1117771

Ranse, J. \& Arbon, P., 2008, 'Graduate nurses' lived experiences of in-hospital resuscitation: a hermeneutic phenomenological approach'. Australian Critical Care 21(1), 38-47. http://dx.doi.org/10.1016/j.aucc.2007.12.001, PMid:18206382

Remote Health Atlas, 2007, 'Resuscitation trolley' viewed 16 February 2012 from http://remote healthatlas.nt.gov.au/resuscitation_trolley.pdf

Resuscitation Council of the United Kingdom, 2004, 'Recommended equipment for in-hospital resuscitation', viewed 17 January 2007, from http://www.resus.org. uk/pages/equip/HAR/htm

Shuster, M. 2006, 'Emergency cardiovascular care guidelines', Canadian Journal of Emergency Medicine 8(1), 37-42.

Smith, A., Kinross, J., Bailey, M., Aggarwal, R., Toresen, D. \& Vincent, C., 2008 'Restocking the resuscitation trolley: how good is compliance with checking procedures'? Clinical Risk 14(1), 4-7. http://dx.doi.org/10.1258/cr.2007.070008

Spearpoint, K., 2008, 'Resuscitating patients who have a cardiac arrest in hospital', Nursing Standard 23(14), 48-57.

Strzyzewski, N., 2006, 'Common erros made in resuscitation of respiratory and cardiac arrest', Plastic Surgical Nursing 26(1), 10-16. PMid:16543851

Suraseranivongse, S., Chawarechai, T., Saengsung, P. \& Komoitri, C., 2006, 'Outcome of cardiopulmonary ressucitation in a 2300 bed hospital in a developing country', Resuscitation 71(2), 188-193. 